\title{
Fruiting as a Factor in Accumulation of Carbohydrates and Nitrogen and in Fall Cold Hardening of Day-neutral Strawberry Roots
}

\author{
Bernard Gagnon $^{1}$, Yves Desjardin' ${ }^{2}$ and Roger Bédard ${ }^{3}$ \\ Département de Phytologie, Faculté des Sciences de l'Agriculture et de l'Alimentation, Université \\ Laval, Qué. G1K 7P4, Canada \\ Additional index words. Fragaria ×ananassa, Junebearers, starch, temperature, freezing test
}

\begin{abstract}
Nitrogen and carbohydrate content of roots and the onset of crown cold hardiness were compared in 'Tristar' day-neutral (DN) strawberries (Fragaria x ananassa Duch.) that were given various fruit removal treatments. Nontreated 'Hecker' DN and 'Redcoat' Junebearer were also used to determine genotypic variation. The removal of fruit after 15 or 30 Sept. promoted the accumulation of starch and increased cold tolerance of crowns as compared to fruiting plants. Nitrogen was increased only when fruit was removed after 15 Sept. DN cultivars were less hardy than Junebearing cultivars, but 'Tristar' was almost as hardy as 'Redcoat'. When compared to 'Redcoat', DN cultivars had a less abrupt temperature-kill profile, perhaps because they were multicrowned.
\end{abstract}

Junebearing strawberry productivity has been correlated with the amount of $\mathrm{N}$ and starch found in storage organs the previous fall (Long, 1935). Unlike Junebearing cultivars (Durner et al., 1984; Greve, 1936; Long, 1935; Maas, 1986), DN strawberries are insensitive to the length of the photoperiod for the accumulation of carbohydrates in roots (Durner et al., 1984). In addition, continuous fruiting inhibits the accumulation of reserves (Forney and Breen, 1985; Olsen et al., 1985) and the development of vegetative organs (Forney and Breen, 1985). These factors can significantly reduce winter survival and productivity the following summer. The use of cultural practices contributing to the partitioning and availability of photosynthates to the roots and crowns should maintain plant health during winter and thus contribute to the profitability of DN strawberries in northern climates.

Cold tolerance of strawberry plants has been evaluated using several techniques. Recovery tests and crown-tissue browning tests have been reliable and accurate methods for the evaluation of cold injury (Stergios and Howell, 1973). Recently, a method has been described that quantifies the intensity of crown injury and correlates it to subsequent survival and flowering (Bolduc and Paquin, 1987). Although this technique is useful, it does not use computational methods such as the Spearman-Karber (Finney, 1964) or probit analysis, both of which may define more precisely the thermal limits tolerated by overwintering plants. A linear relationship exists between the extent of damage to crowns and growth and/or productivity after cold injury (Bolduc and Paquin, 1987; Marini and Boyce, 1979). Therefore, a method may be developed to analyze cold injury using both a descriptive approach (the recovery or crown-browning test) and a statistical test based on quantal response data like the Spearman-Karber method.

We therefore 1) determined the effect of fall fruiting on the

\footnotetext{
Received for publication 24 Jan. 1989. We are grateful to the Agriculture Canada Research Station in Ste-Foy (Quebec) for supplying research facilities and R. Pouliot, P. Lechasseur, and J. Debroux for their technical assistance. This research was supported in part by an NSERC scholarship. The cost of publishing this paper was defrayed in part by the payment of page charges. Under postal regulations, this paper therefore must be hereby marked advertisement solely to indicate this fact.

${ }^{1}$ Graduate student.

${ }^{2}$ Research assistant

${ }^{3}$ Profcssor.
}

cold tolerance of crowns of DN strawberry cultivars, 2) evaluated the importance of carbohydrate and $\mathrm{N}$ reserves on winter survival of two DN and one Junebearing strawberry plants, and 3) applied the Spearman-Kärber method (Bittenbender and Howell, 1974) to a crown tissue-browning test (Bolduc and Paquin, 1987) for a more complete description of cold hardiness in strawberry plants.

\section{Materials and Methods}

All experimental plants were planted on a sandy soil (humoferric podzol) of the St-Nicolas series at Laval Univ. Plants were set in the field on 13 May 1987 under a modified matted-row system, where only three or four daughter plants per mother plant were allowed to root (Galletta, 1985). Plants were spaced $45 \mathrm{~cm}$ apart on rows spaced by $1 \mathrm{~m}$. To facilitate plant establishment, flowers were removed for 42 days after planting (Leblanc et al., 1987).

To determine the effect of fall fruiting on hardening and the accumulation of carbohydrate and $\mathrm{N}$ during the fall, all fruits were removed after blossom for the DN strawberry cultivars Tribute and Hecker and the Junebearing cultivar Redcoat. In addition, 'Tristar' plants were given the following flower removal treatments: fruit and flower removal 1) after 15 Sept., 2) after 30 Sept., and 3) no flower removal. Treatments were randomly distributed to three blocks corresponding to sampling dates in the fall.

Experimental plots were fertilized before planting with $48 \mathrm{~N}$ 96P-96K $\left(\mathrm{kg} \cdot \mathrm{ha}^{-1}\right)$ and three more times from mid-June to the end of July with $\mathrm{NH}_{4} \mathrm{NO}_{3}$ as a granular formulation at $35 \mathrm{~kg} \cdot \mathrm{ha}^{-1}$. A 15-cm-deep straw mulch was applied on 6 Nov. as winter protection. Harvest began on 28 July and ended on 8 Oct. 1988.

Evaluation of cold hardiness. Cold hardening was determined using a method developed for alfalfa (Paquin, 1977). During the fall, 20 plants per flower removal treatment were sampled at three digging dates (23 Sept., 14 Oct., and 4 Nov.), and groups of five plants were submitted to various controlled freezing temperatures $(0,-2,-4,-6 \mathrm{C}$ on 23 Sept., $0,-4,-6$, and $-8 \mathrm{C}$ on 14 Oct., and $0,-4,-6,-8$, and $-10 \mathrm{C}$ on 4 Nov.). On each sampling date, mother plants were dug and potted in $10-\mathrm{cm}$ pots $(\approx 0.5$ liter $)$ and transferred to a greenhouse

Abbreviations: $\mathrm{DN}$, day-neutral; $\mathrm{LT}_{50}$, lethal temperature for $\mathrm{SO} \%$ of flower buds; TNSC, total nonstructural carbohydrates. 
at 20/18 $\pm 1 \mathrm{C}$ day/night at the Agriculture Canada Research Station in Ste-Foy, where freezing tests were conducted. Soil moisture was carefully monitored and uniformly maintained to prevent any modification in the hardening process.

At the time of the freezing test, plants were randomly distributed to two shelves in a $0.7-\mathrm{m}^{3}$ freezer equipped with two fans. Plants were frozen at a rate of $1 \mathrm{C} / \mathrm{hr}$, and temperature was maintained to allow uniform freezing of soil and plants. Temperature was thus maintained for $8 \mathrm{hr}$ at $-2 \mathrm{C}, 5 \mathrm{hr}$ at $-4 \mathrm{C}, 4$ $\mathrm{hr}$ at $-6 \mathrm{C}, 3 \mathrm{hr}$ at $-8 \mathrm{C}$, and $2 \mathrm{hr}$ at $-10 \mathrm{C}$. Unfrozen plants served as a control. Air and soil temperatures at the crown level on each shelf were measured by thermocouples (K type, chromealuminum, 20 gauge) and recorded on a digital recorder (Omega, 450 AKT; Omega Engineering, Stamford, Conn.). After each test, pots were thawed for 12 to $16 \mathrm{hr}$ at $2 \mathrm{C}$ and then placed in a greenhouse at 20 to $22 \mathrm{C}$ for 5 to 6 weeks.

At the end of this period, crowns were cut longitudinally and tissue browning was evaluated for cold injury according to the method of Bolduc and Paquin (1987). Injury was scored from 0 to 4 , where 4 corresponded to an undamaged plant and 0 corresponded to a dead plant. Crown tissue from undamaged plants (index 4) was white or slightly yellow, turgid and firm. The cambium and lower part of the crown of plants with an index of 3 (slightly affected) were rusty brown, but the central core of the crown remained white. Plants rated 2 were seriously injured by frost as indicated by browning of the cambium; the apex and the buds were still green, but small necrotic spots were apparent. The cambium and the upper section of the crown of plants rated 1 (severely injured) were rusty brown, but the lower section was light to dark brown; root necrosis was also observed. Plants rated 0 , those killed by frost, had dark brown crown tissue, apex and root necrosis were apparent, and tissues were soft and water soaked. A crown injury of 2 has been shown to correspond to the critical level of injury, but one at which strawberry plants still can produce flowers (Bolduc and Paquin, 1987). $\mathrm{LT}_{50}$, as modified by Bittenbender and Howell (1974), was determined by plotting the injury rating against temperature.

Carbohydrate and nitrogen measurements. The accumulation of reserves in roots was determined by calorimetry from previously dried samples. Measurements were taken on two samples of each treatment. At each sampling date, mother plants were dug and their roots were cut, washed, dried, ground, and the percent dry matter was determined. Sugars were extracted for a week at $0 \mathrm{C}$ with 12 methanol: 5 chloroform: 2 water (by volume) (Paquin and Lechasseur, 1979). About $100 \mathrm{mg}$ of dried plant material was extracted by $5 \mathrm{ml}$ of solvant. After centrifugation at $2500 \mathrm{rpm}(1000 \times \mathrm{g})$ for $5 \mathrm{~min}$ and decanting and separation of the supernatant, the pellet was reextracted twice with $5 \mathrm{ml}$ of solvant. Supernatants were combined, giving a total solution containing $15 \mathrm{ml}$ of solvant. The pellet was kept for nonsoluble starch determination. Water $(4.5 \mathrm{ml})$ and chloroform $(1 \mathrm{ml})$ were added to separate the solvent into the chloroform and water-alcohol fractions. The latter contained the soluble carbohydrates. The water-alcohol extract $(2 \mathrm{ml})$ was further purified with solutions of barium hydroxide $(2.0 \mathrm{ml})$, zinc sulphate $(3.0 \mathrm{ml})$, and benzoic acid $(3.0 \mathrm{ml})$ (Blakeney and Mutton, 1980). Extracts were left to settle for $24 \mathrm{hr}$ at 0C. A 1-ml aliquot was used to determine reducing sugars in the extract by calorimetry (415 nm) (Blakeney and Mutton, 1980) and a glucose standard curve. An aliquot of $0.5 \mathrm{ml}$ was enzymatitally digested $[0.5 \mathrm{ml}$ invertase (EC 3.2.1.26), 25 units $/ \mathrm{ml}]$, and total soluble sugars were measured by calorimetry. Sucrose concentration was obtained by subtracting reducing sugars from total soluble sugars. Nonsoluble starch present in the pellet was also determined by calorimetry with a $0.2-\mathrm{ml}$ aliquot. Starch was hydrolized by gelatinization in the presence of water (5.0 $\mathrm{ml}$ ) at $100 \mathrm{C}$ for $90 \mathrm{~min}$ followed by digestion with a solution of amyloglucosidase (EC 3.2.1.3) $(5.0 \mathrm{ml}, 10$ units $/ \mathrm{ml})$ at $55 \mathrm{C}$ for $60 \mathrm{~min}$ (Haslemore and Roughan, 1976). The concentration of TNSC was obtained by adding total soluble sugars (reducing sugars and sucrose) to starch.

Nitrogen was determined by a Kjeldahl method (Varley, 1966) with dried sample $(\approx 100 \mathrm{mg})$ previously acid-digested. Measurements were taken by calorimetry on a Technicon autoanalyzer (Technicon, Terrytown, N.Y.).

Statistical analysis. Each variable was subjected to an analysis of variance (GLM-SAS) and means were compared using orthogonal contrasts (SAS Institute, 1985). The experiments on cold hardening and carbohydrate and $\mathrm{N}$ content were analyzed as a randomized complete-block design with three and four sampling dates, respectively, as blocks.

The inverse of the slope of the temperature survival curve through the LT, point, defined as statistic S (Bittenbender and Howell, 1974), also was used in the analysis of results. This value is a mathematical expression of the distribution of the plant survival along the temperature scale. It provides a statistic to compare temperature-survival curves of cultivars grown in various environments or genotypic variation. A low $S$ value would mean that, within a narrow range of temperature around the $\mathrm{LT}_{50}$, percent survival would decline rapidly, whereas a high value would represent a more gradual decline in percent survival around the $\mathrm{LT}_{50}$ point. Standard errors were used for comparison among sampling dates. Finally, a correlation analysis was performed between the cold tolerance data $\left(\mathrm{LT}_{50}\right)$ vs. dry weight, sugars, and $\mathrm{N}$ in roots.

\section{Results}

Fruiting significantly reduced the accumulation of $\mathrm{N}$ in roots relative to all other treatments (Table 1). Nitrogen increased when fruits were removed on 15 or 30 Sept. Removing fruits on 15 Sept. stimulated the accumulation of starch and increased the TNSC content. Treatments had no effect on percent dry matter, reducing sugars, and sucrose content (data not shown). Fruiting prevented plant hardening by reducing the $\mathrm{LT}_{50}$ (Table

Table 1. Effect of fruiting on accumulation of $\mathrm{N}$ and carbohydrates in roots of DN 'Tristar' strawberry plants during the fall (23 Sept. to 25 Nov.).

\begin{tabular}{|c|c|c|c|}
\hline Treatment & Total N & Starch & TNSC \\
\hline & \multicolumn{3}{|c|}{$(\mathrm{mg} / 100 \mathrm{mg}$ dry wt) } \\
\hline Continuous fruiting & $1.10^{\mathrm{z}} \mathrm{C}$ & $7.1 \mathrm{~b}$ & $11.4 \mathrm{~b}$ \\
\hline Fruiting until 15 Sept. & $1.28 \mathrm{a}$ & $8.9 \mathrm{a}$ & $14.0 \mathrm{a}$ \\
\hline Fruiting until 30 Sept. & $1.15 \mathrm{~b}$ & $8.6 \mathrm{ab}$ & $13.2 \mathrm{ab}$ \\
\hline Deblossomed & $1.27 \mathrm{a}$ & $9.3 \mathrm{a}$ & $14.2 \mathrm{a}$ \\
\hline \multicolumn{4}{|l|}{ Significance } \\
\hline$P$ value (treatment) & 0.0001 & 0.0331 & 0.0385 \\
\hline \multicolumn{4}{|l|}{ Contrasts } \\
\hline Effect of fruiting (1,2,3 vs. 4) & 0.0006 & NS & NS \\
\hline $\begin{array}{l}\text { fruits in September (1 vs. } 2,3) \\
\text { Intra-fruit removal dates }\end{array}$ & 0.0003 & 0.0142 & 0.0160 \\
\hline (1 vs. 2$)$ & 0.0004 & NS & NS \\
\hline
\end{tabular}

${ }^{\mathrm{z}}$ Mean separation within columns with Waller-Duncan multiple range test at $P=0.05$.

${ }^{\mathrm{NS}}$ Nonsignificant 
Table 2. Effect of fruiting on cold hardiness of DN 'Tristar' strawberry plants during the fall ( 23 Sept. to 4 Nov.). ${ }^{\mathrm{z}}$

\begin{tabular}{lcc}
\hline \hline Treatment & $\mathrm{LT}_{\text {so }}$ & $\mathrm{S}^{\mathrm{y}}$ \\
\hline Continuous fruiting & $-4.87 \mathrm{c}$ & 0.0072 \\
Fruiting until 15 Sept. & $-5.31 \mathrm{~b}$ & 0.0080 \\
Fruiting until 30 Sept. & $-5.30 \mathrm{ab}$ & 0.0079 \\
$\begin{array}{l}\text { Deblossomed } \\
\text { Significance }\end{array}$ & $-5.76 \mathrm{a}$ & 0.0073 \\
$\quad P$ value (treatment) & 0.0131 & 0.6694 \\
$\begin{array}{l}\text { Contrasts } \\
\quad \text { Effect of fruiting (1,2,3 vs. 4) }\end{array}$ & 0.0006 & NS \\
$\quad \begin{array}{l}\text { Effect of removing } \\
\quad \text { fruits in September (1 vs. 2,3) }\end{array}$ & 0.0055 & NS \\
$\quad \begin{array}{l}\text { Intra-fruit removal dates } \\
\quad(1 \text { vs. 2) }\end{array}$ & NS & NS \\
\hline
\end{tabular}

${ }^{\mathrm{z}}$ Mean separation within columns with Waller-Duncan multiple range test at $P=0.05$.

${ }^{\mathrm{y}} \mathrm{S}$ statistic (Bittenbender and Howell, 1974), see text.

${ }^{\mathrm{NS}}$ Nonsignificant.

Table 3. Correlation coefficient between cold tolerance $\left(\mathrm{LT}_{50}\right)$ and dry weight, $\mathrm{N}$, and carbohydrate content in roots of strawberry plants (23 Sept. to 4 Nov.).

\begin{tabular}{lc}
\hline \hline & Correlation coefficient \\
\hline Dry weight & $-0.803^{* *}$ \\
Reducing sugars & $-0.566^{*}$ \\
Sucrose & $-0.184^{\mathrm{NS}}$ \\
Starch & $-0.936^{* *}$ \\
TNSC & $-0.932^{* *}$ \\
Total N & $-0.918^{* *}$
\end{tabular}

NS,$* * *$ Nonsignificant or significant at $P=0.05$ or 0.01 , respectively.

Table 4. Influence of the genotype on hardening of strawberry plants during the fall (23 Sept. to 4 Nov.). ${ }^{\mathrm{z}}$

\begin{tabular}{lcc}
\hline \hline Cultivar & $\mathrm{LT}_{50}$ & $\mathrm{~S}^{\mathrm{y}}$ \\
\hline Tristar & $-5.76 \mathrm{~b}$ & $0.0073 \mathrm{ab}$ \\
Hecker & $-4.98 \mathrm{a}$ & $0.0083 \mathrm{a}$ \\
Redcoat & $-5.86 \mathrm{~b}$ & $0.0055 \mathrm{~b}$ \\
$\quad$ Significance & 0.0004 & 0.0481 \\
$\quad P$ value (treatment) & & \\
Contrasts & 0.0011 & 0.0247 \\
$\quad$ Photoperiodic type (1,2 vs. 3) & 0.0003 & $\mathrm{NS}$ \\
$\quad$ Intra-type variation (1 vs. 2) & & \\
\hline
\end{tabular}

'Mean separation within columns with Wailer-Duncan multiple range test at $P=0.05$.

${ }^{\mathrm{y}} \mathrm{S}$ statistic (Bittenbender and Howell, 1974).

${ }^{\mathrm{NS}}$ Nonsignificant.

2), but did not affect $S$ values. Removing fruits in September enabled the plants to withstand significantly lower temperatures than if fruits were left on the plant during the whole season. For the period 23 Sept. to 4 Nov., dates at which $\mathrm{LT}_{50}$ was calculated, increased hardiness was closely correlated with percent dry weight, accumulation of starch, TNSC, and total $\mathrm{N}$ (Table 3).

Before the occurrence of the continuous severe frost, fruiting had an influence on the content in total $\mathrm{N}$ reserves, starch, and TNSC stored in roots (Fig. $1 \mathrm{~B}$, E, and F). Moreover, the presence of fruits delayed the cold acclimation of the plants (Fig. 2, top). Removing fruits in early fall enabled the plant to increase accumulation of reserves in the storage sites, so levels of N, starch, sucrose, and TNSC were comparable to nonfruiting plants. For example, removing fruits on $15 \mathrm{Sept}$. resulted
Table 5. Influence of genotype on accumulation of $\mathrm{N}$ and carbohydrates in roots of strawberry plants during the fall (23 Sept. to 25 Nov.). ${ }^{\mathrm{z}}$

\begin{tabular}{lcc}
\hline \hline Cultivar & Total N & Sucrose \\
\hline & $(m g / 100 ~ m g$ & $d r y ~ w t)$ \\
Tristar & $1.10 \mathrm{c}$ & $3.4 \mathrm{a}$ \\
Hecker & $1.20 \mathrm{~b}$ & $2.6 \mathrm{~b}$ \\
Redcoat & $1.29 \mathrm{a}$ & $2.9 \mathrm{ab}$ \\
Significance & & \\
$\quad P$ value (cultivars) & 0.0393 & 0.0970 \\
Contrasts & & \\
$\quad$ Photoperiodic type $(1,2$ vs. 3) & $\mathrm{NS}$ & $\mathrm{NS}$ \\
$\quad$ Intra-type variation (1 vs. 2) & 0.0404 & 0.0411 \\
\hline
\end{tabular}

${ }^{\mathrm{z}}$ Mean separation within columns with Waller-Duncan multiple range test at $P=0.05$.

in a temporary rise in the level of sucrose as compared to other treatments (Fig. 1D)

On 4 Nov., after successive frosts, the accumulation of starch and TNSC was greatest on deblossomed plants (Fig. $1 \mathrm{E}$ and F). However, on 25 Nov., these differences had disappeared. The intensity of hardiness at the beginning of this period followed a similar trend and remained less for plants allowed to fruit until the frosts (Fig. 2, top). Nitrogen levels in plants that were deblossomed or had fruit removed after 15 Sept. were consistently higher than those in other treatments (Fig. 1B). The increase in the percent dry weight was constant during the fall (Fig. 1A), although the treatments produced inconsistent trends. Overall, reducing sugars and sucrose (Fig. $1 \mathrm{C}$ and D) increased from 4 to 25 Nov., perhaps representing a conversion of starch, which decreased during that period. Starch had increased dramatically during the previous period (Fig. 1E).

'Redcoat' was significantly more hardy and, as judged by $\mathrm{LT}_{50}$, had a lower S value than 'Hecker' (Table 4). 'Tristar' accumulated more sucrose and less total $\mathrm{N}$ than 'Hecker' and exhibited significantly higher rates of cold hardening as measured by LT $_{50}$ than either 'Hecker' or 'Redcoat' (Tables 4 and 5). Throughout the fall, the three cultivars hardened in a similar pattern (Fig. 2, bottom). However, 'Hecker' was more susceptible to low temperatures at every sampling date. There was no difference among cultivars for dry-matter accumulation, reducing sugars, starch, and TNSC content (data not shown).

\section{Discussion}

Although cultivar choice is critical, the importance of appropriate management of fruiting during the fall for DN strawberry plants cannot be overstated. As was previously observed in woody plants, acclimation can be seriously impaired in trees or shrubs with depleted photosynthetic reserves, resulting in freeze-induced injury (Janick, 1986; Weiser, 1970). However, since DN strawberry plants retain leaves in the fall, removing fruit before the advent of the first frosts allows the reestablishment of nutritional reserves and contributes significantly to cold tolerance. The rapidity of the plant response to hardening depends on the nature of the metabolites involved. For example, there was a significant difference for the fruit removal dates for $\mathrm{N}$, whereas no 30 Sept. vs. continuous fruiting difference was observed for starch content (Table 1).

Under climatic conditions prevailing in Quebec $\left(47^{\circ} \mathrm{N}\right)$, temperature is evidently the main factor contributing to the accumulation of reserves and to the acclimation of DN strawberry plants. DN cultivars, considered insensitive to photoperiod for the accumulation of carbohydrates (Durner et al., 1984) and for 

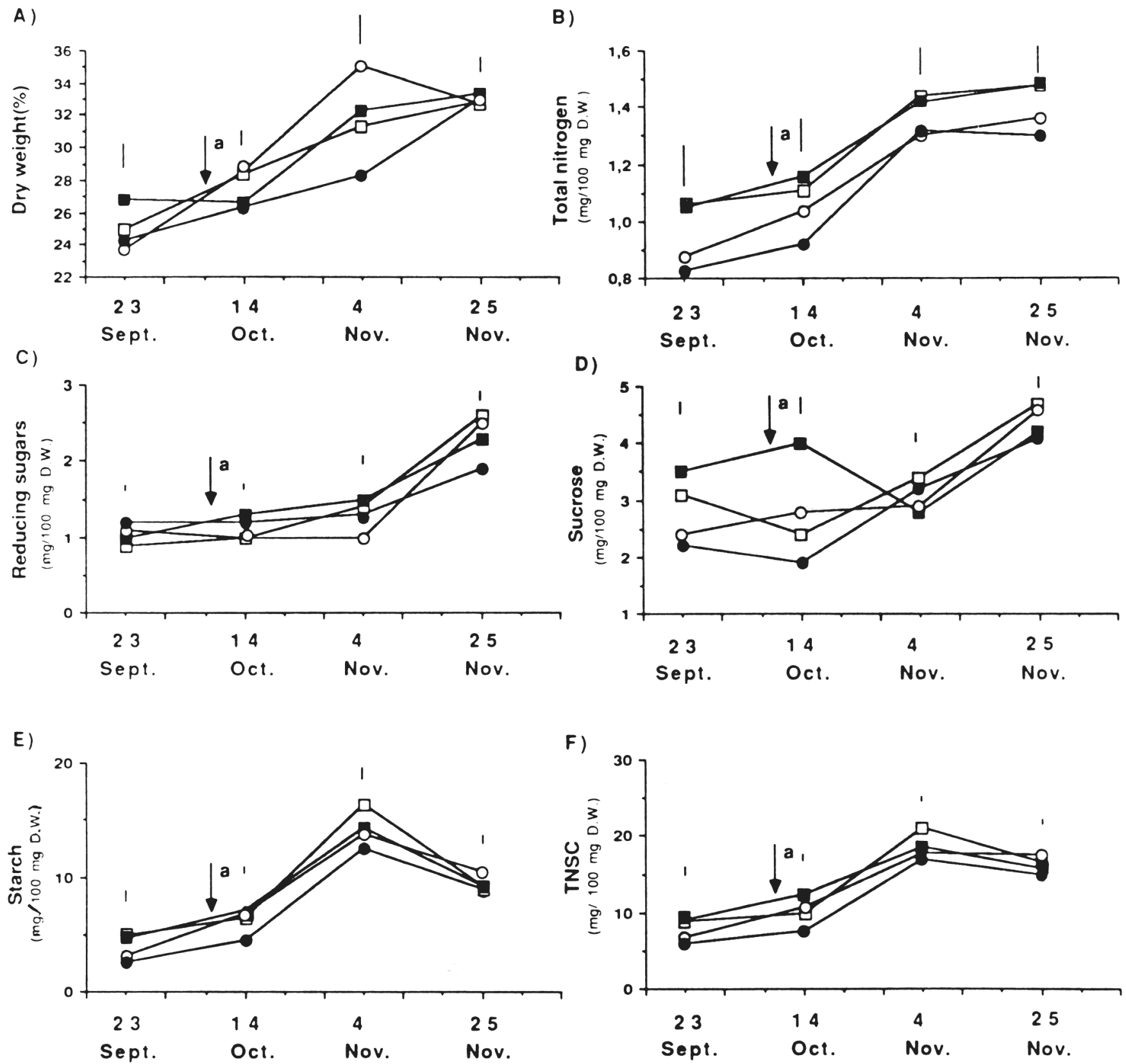

Fig. 1. Influence of fruiting on (A) percent dry weight, (B) total N, (C) reducing sugars, (D) sucrose, (E) starch, and (F) TNSC content of 'Tristar' strawberry roots during the fall. The occurrence of the first frost below - 1C is indicated by an arrow. Deblossomed ( $\square$ ); fruit removed starting 15 Sept. ( $\mathbf{\square})$ or 30 Sept. ( $\bigcirc$ ); continuous fruiting $(\bullet)$.

the onset of dormancy (Gast and Pollard, 1986), had N, starch, and hardening accumulation patterns comparable to those of a hardy Junebearing cultivar. Evidently, in strawberry and other plants, cold acclimation and bud dormancy are independent (Irving and Lanphear, 1967) and temperature is the most important factor in the acquisition of cold tolerance (Weiser, 1970). In addition, the lack of hardiness of 'Hecker' could be explained by a difference in the native genetic capacity to tolerate cold, not by a failure to acclimate.

DN strawberry plants possess some very interesting winter survival characteristics. These cultivars are less resistant to cold than Junebearers at moderately low temperatures, as can be inferred from their higher $\mathrm{LT}_{50}$. However, as a result of their higher $\mathrm{S}$ values, DN plants also have the possibility of surviving and producing following exposure to temperatures below the
$\mathrm{LT}_{50}$, since the slope of the temperature-survival curve is not as steep as that of Junebearers. This high $\mathrm{S}$ value might be a consequence of their crown-branching habit that provides the opportunity for multiple cold tolerances on a single plant. It remains to be verified if the surviving crowns have the capacity to reestablish a profitable production after a severe winter frost.

Finally, the determination of $\mathrm{LT}_{50}$ of flower buds from data gathered from crown-browning tests is an adequate method for the evaluation of strawberry cold hardiness. However, more research will be needed to determine more precisely the advantages of this method over the more conventional ones.

To summarize, fruit removal in the fall is a sound practice in northern climates, since it allows a higher accumulation of reserves in roots and improves the cold tolerance and winter survival of DN strawberry cultivars. Moreover, this practice does 

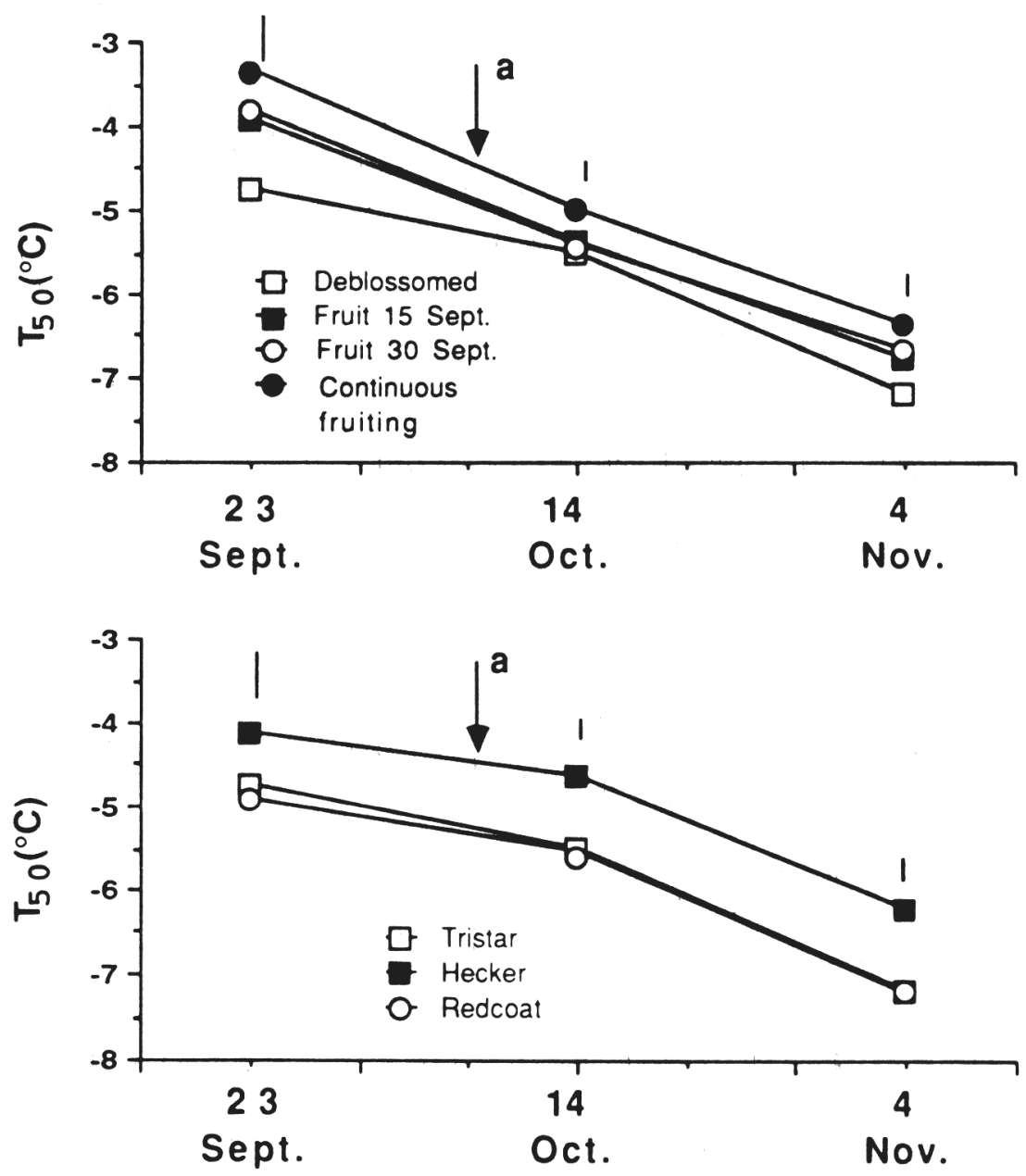

Fig. 2. Influence of fruiting (top) and genotype (bottom) on the evolution of cold tolerance, as measured by the $\mathrm{LT}_{50}$, of strawberry plants during the fall. The occurrence of the first frost below $-1 \mathrm{C}$ is indicated by the letter a.

not significantly reduce the marketable yield, since growth and production during this period of the year are marginal, fruits are of lesser quality, and ripening is slower. However, the economics of flower removal in the fall are questionable and other practices should be sought to prolong the lifespan and profitability of this new type of strawberry. In this respect, factors improving the state of nutritional reserves should be investigated to improve winter survival of DN strawberries.

\section{Literature Cited}

Bittenbender, H.C. and G.S. Howell, Jr. 1974. Adaptation of the Spearman-Kaber method for estimating the $\mathrm{T}_{50}$ of cold stressed flower buds. J. Amer. Soc. Hort. Sci. 99:187-190.

Blakeney, A.B. and L.L. Mutton. 1980. A simple calorimetric method for the determination of sugars in fruit and vegetables. J. Sci. Food Agr. 31:889-897.

Bolduc, R. and R. Paquin. 1987. Comparaison de deux methodes d'évaluation de la tolerance au gel du fraisier prélevé dans un sol gelé. Can. J. Plant Sci. 67:343-348.

Durner, E.F., J.A. Barden, D.G. Hilmerick, and E.B. Poling. 1984. Photoperiod and temperature effects on flower and runner development in day-neutral, Junebearing and everbearing strawberries. J. Amer. Soc. Hort. Sci. 109:396-400.

Finney, D.J. 1964. Statistical methods in biological sciences assay. Second ed. Hafner, New York.

Forney, C.F. and P.J. Breen. 1985. Dry matter partitioning and assimilation in fruiting and deblossomed strawberry. J. Amer. Soc. Hort. Sci. 110:181-185.
Galetta, G.J. 1985. Strawberry production trends in the eastern United States. Compte rendu du symposium sur la culture de la fraise, Quebec, Canada. C.P.V.Q., Agdex 230/20. p. 99-115.

Gast, K. and J. Pollard. 1986. Temperature effects on photosynthesis and carbon metabolism in Fragaria xananassa Duch. HortScience 21:895. (Abstr.)

Greve, E.W. 1936. The effect of shortening the length of day on flower-bud differentiation and on the chemical composition of strawberry plants grown during the normal growing season. Proc. Amer. Soc. Hort. Sci. 34:368-371.

Haslemore, R.M. and P.G. Roughan. 1976. Rapid chemical analysis of some plant constituents. J. Sci. Food Agr. 27:1171-1178.

Irving, R.M. and F.O. Lanphear. 1967. Environmental control of cold hardiness in woody plants. Plant Physiol. 42:1191-1196.

Janick, J. 1986. Horticultural science. 4th ed. W.H. Freeman, New York.

Leblanc, M., Y. Desjardins, R. Bédard, and A. Gosselin. 1987. The effect of blossom removal on production characteristics of day-neutral strawberry plants grown in northern climates. Adv. Strawberry Production 6:23-26.

Long, J.H. 1935. Seasonal changes in nitrogen and carbohydrate content of strawberry plants. Proc. Amer. Soc. Hort. Sci. 33:386388.

Maas, J.L. 1986. Photoperiod and temperature effects on starch accumulation in strawberry roots. Adv. Strawberry Production 5:2224.

Marini, R.P. and B.R. Boyce. 1979. Influence of low temperatures during dormancy on growth and development of 'Catskill' strawberry plants. J. Amer. Soc. Hort. Sci. 104:159-162. 
Olsen, J.L., L.W. Martin, P.J. Pelofske, P.J. Breen, and C.F. Forney. 1985. Functional growth analysis of field grown strawberry. J. Amer. Soc. Hort. Sci. 110:89-93.

Paquin, R. 1977. Effet des basses tempiratures sur la résistance au gel de la luzerne (Medicago media Pers.) et son contenu en proline libre. Physiol. Veg. 15:657-665.

Paquin, R. and P. Lechasseur. 1979. Observation sur une méthode de dosage de la proline libre dans les extraits de plantes. Can. J. Bot. 57:1851-1854.
SAS Institute, Inc. 1985. SAS user's guide: Statistics. version 5. SAS Institute, Inc., Cary, N.C.

Stergios, B.G. and G.S. Howell, Jr. 1973. Evaluation of viability test for cold stressed plants. J. Amer. Soc. Hort. Sci. 98:325-330.

Varley, J.A. 1966. Automatic method for the determination of nitrogen, phosphorus and potassium in plant material. Analyst 9:118 126.

Weiser, C.J. 1970. Cold resistance and injury in woody plants. Science 169:1269-1278 